\title{
Scottish national Antarctic expedition - Outline map of Laurie Island, South Orkneys, 1903
}

\section{William S. Bruce}

To cite this article: William S. Bruce (1905) Scottish national Antarctic expedition - Outline map of Laurie Island, South Orkneys, 1903, Scottish Geographical Magazine, 21:6, 322-323, DOI: $10.1080 / 00369220508733576$

To link to this article: http://dx.doi.org/10.1080/00369220508733576

Published online: 27 Feb 2008.

Submit your article to this journal $\square$

Џ Article views: 8

Q View related articles $\square$

Citing articles: 5 View citing articles ๘ 


\title{
SCOTTISH NATIONAL ANTARCTIC EXPEDITION.
}

OUTLINE MAP OF LAURIE ISLAND, SOUTH ORKNEYS, 1903.

\author{
By William S. Bruce.
}

\section{(IVith Map.)}

THIs is a preliminary sketch from a more detailed map which will appear at a later date, the coastline being alone indicated. It is reduced from a two-inch-to-the-mile survey made in co-operation with Dr. J. H. Harvey Pirie, Mr. D. W. Wilton, and Mr. R. N. Rudmose Brown, who took part in the various sledge and boat journeys around the islands during the wintering of the Scotia in Scotia Bay. I am indebted to Captain Thomas Robertson for the latitude and longitude of the Central Cairn, which is approximately $60^{\circ} 44^{\prime} \mathrm{S} .44^{\circ} 50^{\prime} \mathrm{W}$., and to Mr. Robert C. Mossman for the observations on Magnetic Declination, the variation being $5^{\circ} 15^{\prime} \mathrm{E}$. I have thought it important to publish this preliminary map, especially in the interests of navigation, as all previously existing maps are very far from correct. The survey having been carried out with the greatest care, there need be no doubt whatever about any part of the coast, except about 3 miles of the west coast of Mackenzie Peninsula and the west side of Eillium Isle, and even these are approximately correct. The position of Cape Roca, named after the President of the Argentine Republic, is, however, correct, as well as Cape Robertson and Cape Davidson. The west coast of Pirie Peninsula in fainter line was not surveyed in such detail as the remaining portion, but it is very approximately correct. In this reduced map no attempt has been made to show the nature of the interior, or of the bottom of the sea as depicted by about 500 soundings. A number of names have been omitted. In spite of the previous defective charts the names Route Point, Cape Vallavielle, Cape Dundas, and Murray Isles have been retained in recognition of the splendid services of Powell, Weddell, and D'Urville, whose short stays at the South Orkneys did not enable them to carry out detailed survey.

The island is a most remarkable one as far as shape is concerned, consisting of a series of narrow peninsulas, four of which (Mackenzie, Pirie, Fergusile, and Watson Peninsulas) point northwards with deep bays (Jessie, Brown, and Macdougal Bays) between them. Another, Mossman Peninsula, forms the western boundary of Scotia Bay, while at the eastern end of the island comes Ferrier Peninsula, with Cape Dundas at its extremity. Between Uruguay Cove and Scotia Anchorage the island is almost divided into two, there being at this point the only lowlying piece of ground of any extent in the whole island. On this, The Beach, are situated the Central Cairn, Omond House, and Copeland Observatory. In Fitchie Bay is Graptolite Island, so named from Dr. Pirie's important find there of fossils which have determined the age of the South Orkney Rocks, and which, along with those of the Swedish 
Expedition, form our only present contribution towards a knowledge of the palæontology of the Antarctic Regions.

The titles of the illustrations of Laurie Island, which have already appeared in this Magazine, may be amplified from the accompanying map, as follows :-

Frontispiece, facing p. 57, rol. xx. (1904): Scotia in Scotia Bay, hills of Mossman Peninsula in background.

Fig. 1, vol. xxi. (1905) p. 24 : Omond House, on "The Beach."

Fig. 2, vol. xxi. p. 25 : Weddell and Saddle Islands, South Orkneys.

Fig. 6, vol. xxi. p. 31 : Watson Peninsula, from camp on east side of Ferguslie Peninsula in Macdougal Bay.

Fig. 7, vol. xxi. p. 32: Cape Dundas and Ferrier Peninsula at eastern extremity of Laurie Island.

Fig. 8, vol. xxi. p. 33 : Glacier at head of Macdougal Bay, from camp on east side of Ferguslie Peninsula.

\section{THE RECENT VOYAGE OF THE URUGUAY.}

\section{By R. C. Mossman, F.R.S.E.}

\section{(With Chart and Illustrations.)}

THE Argentine sloop-of-war Uruguay, under the command of Captain Ismael Galindez, left Buenos Ayres on December 10 for the South Orkney Islands to relieve the meteorological observers left there by the Scotia on her return south in February 1904. After calling at Ushuaia for coal and water, a course was shaped for Saddle Island. On the 30 th at 4 A.M., when in latitude $58^{\circ} 30^{\prime} \mathrm{S}$. and longitude $51^{\circ} 16^{\prime} \mathrm{W}$., the first iceberg was encountered. It was of triangular form and one mile long, while that portion above the sea was estimated at 150 feet. Soon after the pack-ice was fallen in with, while the ship was yet distant 250 miles from the Orkneys. At first it was loose, but close to the islands, or in lat. $59^{\circ} 45^{\prime} \mathrm{S}$., long. $46^{\circ} 30^{\prime} \mathrm{W}$., some very heavy and compact pack was met with. Fortunately there was open water on the north side of Coronation Island. The wind at the Orkneys had been blowing from the south and south-west for over six weeks, so that the pack-ice had been driven a few miles off shore. A further favourable circumstance was the unusual clearness of the atmosphere, which greatly aided navigation. The Unuguay dropped anchor in the north bay (now called Uruguay Cove) at 9 P.M. on December 31. Immediately on her arrival preparations were begun for landing stores and coal for a new party of five men sent down by the Argentine Meteorological Office to continue the work for another year. A new magnetic house for the variometers was in process of erection, and some additional lumber was also landed. The conditions were at first very favourable for this work. The sea in the bay was perfectly still, and there was no swell, so that the numerous packing-cases, sacks of coal, etc., could be put ashore without difficulty and dragged up on the ice-foot. On the morning of January 1 the weather, which had been exceptionally fine and clear, broke down, with thick mist and snow, and as the northerly wind which set in 